\title{
LOGOS E VERDADE: UMA LEITURA FENOMENOLÓGICA PARA O ESBOÇO DE UMA METAFÍSICA DA LINGUAGEM EM PLATÃo
}

\author{
Logos and Truth: a phenomenological reading for a sketch to a metaphysics of language in Plato
}

\author{
Irlim Corrêa Lima Júnior *
}

Resumo: Apoiando-nos em estudos de Heidegger a respeito da filosofia antiga, o qual relê sob a perspectiva de uma hermenêutica fenomenológica os textos herdados pela tradição filosófica, pretendemos no presente trabalho traçar alguns dos aspectos fenomenológicos fundamentais de uma filosofia da linguagem em Platão, no diálogo Crátilo, em relação com a sua metafísica, a fim de proporcionar uma visão de conjunto pela qual seja possível vislumbrar uma relação essencial entre possíveis pressupostos com a derivação "natural" de alguns de seus conceitos. Nesse intento, discorreremos acerca do caráter adventício da verdade, cujo desencobrimento, no qual vêm à luz do ser dos entes, abre os horizontes para uma possível compreensão sistêmica da metafísica platônica. Com efeito, ao identificarmos essencialmente verdade e linguagem, aprofundaremos propriamente nos traços que possibilitam fazer um esboço da íntima conexão entre a filosofia da linguagem em Platão e a sua metafísica. Por fim, procuraremos demonstrar como verdade e linguagem seriam, no fundo, modos de produção e reprodução paradigmática do ser dos entes. Palavras-chave: Platão; Linguagem; Mímesis; Fenomenologia; Heidegger.

\begin{abstract}
Based on the studies of Heidegger concerning the ancient philosophy, which rereads the texts inherited by the philosophical tradition under the perspective of a phenomenological hermeneutic, the intention of this work is to outline some of the fundamental phenomenological aspects of a philosophy of language in Plato, focusing on the dialogue Cratylus, and to establish a relation to his metaphysics, in order to provide an overview according to which it will be possible to glimpse an essential link between the possible assumptions and the "natural" derivation of some of its concepts. In this attempt, it will be discussed the apophantic character of truth, whose uncovering, by which comes to light the Being of the beings, opens horizons for a possible systemic understanding of the Platonic metaphysics. Therefore, by identifying truth and language essentially, the traits that make possible a sketch of the intimate connection between the philosophy of language in Plato and his metaphysics will be properly deepened. Finally, it is intended to demonstrate how both the truth and the language would be, deep down, a paradigmatic mode of production and reproduction of the Being of the beings.
\end{abstract}

Keywords: Plato, Language, Mimesis, Phenomenology, Heidegger.

* Mestrando do Programa de Pós-graduação em Filosofia da PUC-RJ. Bolsista Capes. Email: dinhoirlim@gmail.com

\begin{tabular}{|c|c|l|l|l|l|}
\hline intuitio & $\begin{array}{c}\text { ISSN } \\
1983-4012\end{array}$ & Porto Alegre & Vol.8 $-\mathrm{N}^{\circ} .1$ & $\begin{array}{c}\text { Junho } \\
2015\end{array}$ & p.157-170 \\
\hline
\end{tabular}


Logos e verdade: uma leitura fenomenológica para o esboço de uma metafísica da linguagem em Platão

\section{Introdução}

A pretensão desta investigação é, partindo de uma leitura fenomenológica inspirada em Heidegger, traçar alguns aspectos gerais tocantes à filosofia da linguagem em Platão, em especial no diálogo Crátilo e sua relação com a metafísica, um dos pilares do pensamento ocidental e base para os desdobramentos da Filosofia ao longo dos séculos, seja direta ou indiretamente, de forma mais ou menos sistemática e orgânica. Nosso intuito é proporcionar uma visão de conjunto pela qual seja possível vislumbrar a relação essencial entre alguns de seus pressupostos com a derivação "natural" de seus conceitos. Posto que não contássemos com espaço suficiente e tempo hábil, dispensamo-nos de empreender uma hermenêutica acurada dos textos platônicos - o que se fizera mister e fora bastante enriquecedor - de modo a ratificar mais rigorosamente a compreensão do que aqui propugnamos.

Uma interpretação fenomenológica da obra platônica é perfeitamente possível uma vez que se regresse às fontes das quais seu pensamento bebeu e à originalidade de suas ideias. É evidente que isso esbarra seriamente em limites históricos, culturais, filológicos, políticos, sociais..., mas de alguma forma, ainda que não nos seja franqueado um acesso à historicidade factual de seu contexto, o vigor essencial de seu pensamento ainda é capaz de repercutir até nós, através de novas interpretações, uma compreensão não menos originária que a de seus contemporâneos e não menos fiel a seu espírito.

Como dissemos, uma análise minuciosa do texto platônico está por ora descartada, não nos sendo possível no momento, mesmo porque, na realidade, muitos elementos aqui pensados e relacionados não são objetos centrais nas discussões do Crátilo. Contudo, este diálogo acaba por propiciar uma consideração fenomenológica a respeito do pensamento platônico, posto que, terminando em aporia, não apresenta senão pouquíssimos rastros do que a tradição posterior chamará de seu dogmatismo, como, por exemplo, a doutrina das ideias, a anamnese..., mas sem deixar de ser cioso em relação às questões metafísicas, tal como a relação entre ser e dizer, coisa e palavra... Deste modo, enseja-nos precisamente o que intencionamos: uma análise conjuntural e sintética, mas de modo algum definitiva. Sem necessidade de apelar para o hiperurânio e para rememorações com o fito de resolver tais questões (em cujas discussões não nos debruçamos), o impasse do diálogo obriga-nos a tramitar nos limites fenomenológicos difíceis de serem destrinçados e de serem resolvidos, como a relação entre linguagem, verdade, ser, nome, coisa, representação, mímesis, etc.

Apoiando-nos em estudos de Heidegger a respeito da filosofia antiga, colhidos de diversos textos de autoria do autor, sustentaremos nossas análises, sem pretender propriamente incorrer numa fidelidade estritamente compromissada com o pensamento heideggeriano, cujo projeto alicerça-se justamente na destruição da Metafísica em vista de fazer surgir uma compreensão novamente originária. Nosso propósito

\begin{tabular}{|c|c|l|l|l|l|}
\hline intuitio & $\begin{array}{c}\text { ISSN } \\
1983-4012\end{array}$ & Porto Alegre & Vol.8 $-\mathrm{N}^{\mathrm{o}} .1$ & $\begin{array}{c}\text { Junho } \\
2015\end{array}$ & p.157-170 \\
\hline
\end{tabular}


Logos e verdade: uma leitura fenomenológica para o esboço de uma metafísica da linguagem em Platão

aqui, diversamente, nada mais é do que apresentar de forma panorâmica uma possível estrutura fenomenológica que pudesse se encontrar subjacente à Metafísica de Platão.

\section{O caráter fenomenológico da alétheia}

Que no decorrer da História da Filosofia, a interpretação do conceito de verdade tenha prevalecido a justaposição adequacional entre sujeito e objeto, não é um acontecimento fortuito ou tardio para o desdobramento do pensamento ocidental. Ao contrário, que possui suas justificativas na raiz deste mesmo, foi algo a respeito do que deveras se debateu Heidegger com o intento de denunciar o surgimento da Metafísica como o esquecimento do ser. A condição de possibilidade para este olvidamento, o qual lançou por mais de dois mil e quinhentos anos o sentido primário da verdade nas trevas dos primórdios do pensamento filosófico, período a ser classificado (quase que) definitiva e anacronicamente como filosofia pré-socrática, não obstante tenha aberto espaço para o desencobrimento dos entes enquanto entes, sobre cuja inaugural reminiscência epistemológica, pôde-se fundamentar ao longo dos tempos as ciências teóricas e práticas, teria sido precisamente a guinada filosófica em relação ao conceito de verdade. Quando esta deixou de significar "desvelamento" e passou a indicar "correção", até atingir na Idade Média, com efeito, a formulação clássica da verdade como "veritas est adequatio rei et intellectu", assinalando a verdade como adequação, algo que, perpassando incostete a Idade Moderna, nada obstante a ressignificação de coisa / realidade e intelecto, bem como sua relação e polaridade, só com Nietzsche em fins do século XIX foi agudamente criticado. Se Nietzsche, porém, procurou denunciar essa caracterização objetivante da verdade como imposição arbitrária da vontade de potência e destrui-la, fazendo-a retroceder até às tramas de sua genealogia de onde pôde ser então originada, Heidegger debruçou-se sobre a filosofia antiga esmiuçando hermeneuticamente os traços e cisões pelos quais se deu o processo dessa reviravolta, a fim de clarificar fenomenologicamente como e por que isto se vincula intimamente com o acontecimento histórico do esquecimento do ser, um dos marcos fundacionais da história do Ocidente.

Apelando para uma profunda reflexão filosófica a respeito do étimo da palavra $\alpha \lambda \lambda \dot{\eta} \theta \varepsilon ı \alpha$, cujos limites de pensamento reflexivo não se obrigam a se deter na cientificidade linguística ou filológica, mas extravasam para o campo de uma reflexão trans-histórica e transcendental, Heidegger lança mão de sua origem a partir da raiz do verbo $\lambda \alpha \nu \theta \alpha ́ v \omega(\lambda \alpha \theta-/ \lambda \eta \theta-)$, o qual significa "esconder-se, ocultar-se, olvidarse...". O alfa privativo na formação do vocábulo em questão assinalaria o processo ou movimento contrário a partir do qual o estado de obliteração originário é revertido no assomo da origem, ג’ $\chi \eta ́$ da aparição fenomênica da realidade. A negatividade do alfa nesse contexto, não apenas marcaria o traço da compreensão de verdade como o "não-encoberto, o não-oculto, o não-olvidado", mas também o aspecto conceitual que denotaria o dinamismo pelo qual da verdade se mostra o verdadeiro, como pela $\dot{\alpha} \lambda \eta \dot{\theta} \theta \varepsilon ı \alpha$

\begin{tabular}{|c|c|c|c|c|c|}
\hline intuitio & $\begin{array}{c}\text { ISSN } \\
1983-4012\end{array}$ & Porto Alegre & Vol.8 $-\mathrm{N}^{\circ} .1$ & $\begin{array}{c}\text { Junho } \\
2015\end{array}$ & p.157-170 \\
\hline
\end{tabular}


Logos e verdade: uma leitura fenomenológica para o esboço de uma metafísica da linguagem em Platão

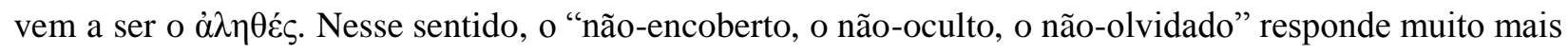
pelo $\dot{\alpha} \lambda \eta \theta \dot{\varepsilon} \varsigma$, ao passo que a própria verdade deve ser entendida como o "desencobrimento, o desocultamento, desolvidamento" que traz à luz o verdadeiro. ${ }^{1} \mathrm{O}$ verdadeiro, então, deve ser visto como o que é retirado das trevas originárias do não- $\operatorname{ser}^{2}$ para o que é trazido à existência e o que enquanto nela vigora; também reside nele o sentido do que, uma vez tendo caído no declínio de não mais vigorar e do estar presente, é trazido de volta pela memória. A verdade indicaria, portanto, tanto a transposição arquifundante do fazer-se real e do desvelamento do ser, quanto a transgressão do evento de queda no ocultamento ou oblívio a que tudo o que é estaria sujeito, transgressão ainda capaz de descortinar o que fora velado no ser.

A significação veritativa do juízo e adequacional da epistemologia, não obstante pareça incrivelmente afastada do sentido originário da verdade, deveria ser compreendida e derivada a partir daí. Com efeito, em linhas breves, posto que não nos seja possível no presente momento senão traçar um parco esboço acerca desse desdobramento, a emissão de um juízo enquanto verdadeiro ou falso requer como condição uma referência ao que se deu como fato ou ao que se mostrou enquanto realidade. Sem querer tocar aqui nas condições lógicas pertinentes à configuração de leis e regras pelas quais seria possível se emitir uma verdade ou falsidade, mas detendo-nos tão somente na condição ontológica que as precede e que é mesmo pré-lógica, é forçoso que antes mesmo de que algo seja dito verdadeiro ou falso, algo tenha se dado, algo tenha surgido enquanto real. Apenas pelo caráter referencial à realidade ser-nos-á possível compreender como que a verdade (desde Platão como ỏ $\theta$ ó $\theta n s$, correção, retidão) passou a sinalizar a

\footnotetext{
${ }^{1}$ Heidegger interpreta “(...) aletheia $(\dot{\alpha} \lambda \hat{\eta} \theta \varepsilon 1 \alpha)$ como desencobrimento. Des-encobrimento é o traço fundamental daquilo que já apareceu e que deixou para trás o encobrimento. Esse é o sentido do alfa $(\alpha)$ privativo na gramática elaborada pelo pensamento grego tardio. A relação com lethe $(\lambda \eta \dot{\theta \eta})$, encobrimento e o próprio encobrimento não perdem de forma alguma o peso pelo fato de se experienciar o descoberto como o que apareceu, como o que entrou em vigência, como vigente.” (HEIDEGGER, Martin. "Aletheia”. In: ___ Ensaios e conferências. Petrópolis: Vozes, 2012, p. 229).

Com efeito, tal descobrimento tem o caráter fundamental de uma abertura, em cujo âmbito dá-se aquilo que se encontra como aberto, o ente. Diz ainda Heidegger alhures: "Este aberto foi concebido pelo pensamento ocidental, desde o seu começo, como tà aléthea, o desvelado. Se traduzimos a palavra aletheia por "desvelamento", em lugar de "verdade", esta tradução não é somente mais "literal", mas ela compreende a indicação de repensar mais originalmente a noção corrente de verdade como conformidade da enunciação, no sentido, ainda incompreendido, do caráter de ser desvelado e do desvelamento do ente." (HEIDEGGER, Martin. "Sobre a essência da verdade". In: . Pensadores: Martin Heidegger - conferências e escritos filosóficos. São Paulo: Abril Cultural, 1996, p. 161). As críticas, contudo, levantadas contra Heidegger quanto a sua interpretação do sentido da verdade entre os gregos, como, por exemplo, o faz Friedländer (cf. INWOOD Michael. Dicionário Heidegger. Rio de Janeiro: Jorge Zahar, 2002, p. 6), ainda que possam proceder etimológica e historiograficamente, não atingem a dimensão em que se move o pensamento heideggeriano. A etimologia sustentada por Heidegger encontra-se no lado diametralmente oposto àquilo que as ciências da linguagem procuram comprovar. Como interpretação fenomenológica, a hermenêutica heideggeriana aponta para a dimensão metafísica, onde o empírico não é apenas metodologicamente suspenso, como também se mostra insuficiente. Nessa região do pensar, as origens fáticas devem dar lugar no pensamento à originariedade ontológica, relativa às estruturas fundamentais do ser, o que abre caminho para aproximações filosóficas de possibilidades puras, isto é, de possibilidades não condicionadas à comprovação empírica, mas à fundamentação fenomenológica.

${ }^{2}$ Não-ser como o não sendo, isto é, de maneira geral, não sendo fenômeno.
}

\begin{tabular}{|c|c|c|c|c|c|}
\hline intuitio & $\begin{array}{c}\text { ISSN } \\
1983-4012\end{array}$ & Porto Alegre & Vol.8 $-\mathrm{N}^{\circ} .1$ & $\begin{array}{c}\text { Junho } \\
2015\end{array}$ & p.157-170 \\
\hline
\end{tabular}


Logos e verdade: uma leitura fenomenológica para o esboço de uma metafísica da linguagem em Platão

adequação do intelecto à coisa ou entre sujeito e objeto. O juízo lógico-veritativo pressupõe, por necessidade, as condições epistemológicas através das quais a adequação entre subjetividade e objetividade é possível, em que ambas são justapostas corretivamente, em vista de se propiciar o conhecimento da coisa ou do objeto tais como são ou se apresentam. Contudo, isto não seria sequer possível sem o advento ontológico da própria realidade , cujo dar-se e mostrar -se é assinalado pelo conceito primário de $\dot{\alpha} \lambda \hat{\eta} \theta \varepsilon ı \alpha$. Por esta razão, esse adventício desencobrimento consiste no fundamento que possibilita - do qual se derivam - todos os demais sentidos epistemológicos e judicativos possíveis do conceito de verdade.

Mas, se esse sentido apresenta-se-nos como primário, o que nele já está em jogo enquanto compreensão originária da realidade e do seu modo de dar-se enquanto verdade? O que é o ser / a realidade ${ }^{3}$ enquanto o que figura na figuração da verdade? E qual é o modo de configuração da verdade que condiciona a realidade que se figura? Em vista dessas questões, convém também pensar o que assinala o conceito de fenômeno e sua essencial atinência à dinâmica e compreensão da própria verdade. $\mathrm{O}$ significado de paıvó $\mu \varepsilon v o v$ é o que se mostra, o que se manifesta, o se-mostrante adveniente da própria mostração através da qual ele se mostra. Assinala Heidegger:

Como significação da expressão "fenômeno" deve-se portanto reter firmemente:

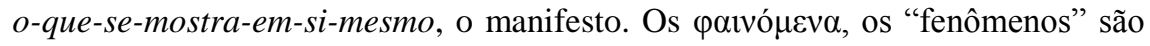
então o conjunto do que está à luz do dia ou que pode ser posto em claro, aquilo

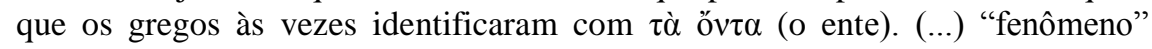
como aparecimento "de algo" não significa, pois, precisamente: mostrar-se a si mesmo, mas o anunciar-se de algo que não se mostra pelo que se mostra ${ }^{4}$.

Fenômeno nunca é, pois, fenômeno de si mesmo - a mostração de um fenômeno supõe uma redução fenomenológica que "desfenomenalize" o que se mostra no fenômeno, a fim de se traçar a configuração geral pela qual o fenômeno fenomenaliza seus "conteúdos" -, mas de um algo que nele e através dele se mostra : os entes ( $\tau \grave{\alpha} v \tau \alpha$ ). Esse aparecimento de algo, contudo, embora se mostre, se anuncie fenomenicamente, nunca se dá como é em si mesmo, mas só a partir do momento em que se fenomenaliza, em outras palavras, torna-se fenômeno, apresenta-se segundo o modo de aparição fenomenal e não na subsistência em si de si mesmo. Assim, o fenômeno é a aparição da coisa que não se mostra se mostrando, do ente que se encontra condicionado à desaparição de como é em si mesmo para aparecer como fenômeno de si mesmo: como o desvelar de si como fenômeno no velamento de si mesmo

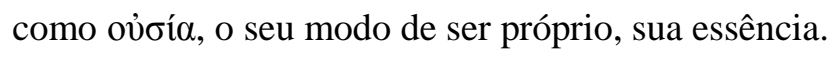

\footnotetext{
${ }^{3}$ Não nos é forçoso ater-nos à distinção propriamente entre ser e ente tal como Heidegger propõe no contexto de seu próprio pensamento. Nada obsta, pois, que nos utilizemos de sua interpretação a respeito de como os filósofos da aurora da metafísica a entreviram. Ser e realidade, pois, devem ser vistos simplesmente como essência (modo de ser de algo determinado, ov̉oía) e quididade (a coisidade da coisa mesma, sua configuração específa, $\varepsilon \notin \delta \varsigma$ ).

${ }^{4}$ HEIDEGGER, Martin. Ser e tempo / Sein und Zeit. Petrópolis: Vozes, 2012, p. 103.
}

\begin{tabular}{|c|c|l|l|l|l|}
\hline intuitio & $\begin{array}{c}\text { ISSN } \\
1983-4012\end{array}$ & Porto Alegre & Vol.8 $-\mathrm{N}^{\mathrm{o}} .1$ & $\begin{array}{c}\text { Junho } \\
2015\end{array}$ & p.157-170 \\
\hline
\end{tabular}


Logos e verdade: uma leitura fenomenológica para o esboço de uma metafísica da linguagem em Platão

Ajuntando aqui o disséramos acerca da $\alpha \dot{\alpha} \lambda \hat{\theta} \theta \varepsilon ı \alpha$ com o que investigamos com o $\quad$ aıvó $\mu \varepsilon v o v, o$ caráter fenomenológico da verdade consistiria, pois, no desvelamento do ente que é trazido à luz fenomenalmente com o velamento de sua própria oủoía. A essência, portanto, é aquilo que por natureza e por modo de figuração do próprio ser real é obliterado no aparecimento: o próprio ocultar-se cuja vigência franqueia a fenomenalização de si como "ausência presente". Não será fortuita, destarte, a necessidade de forçar ao desvelamento da verdade a correção epistemológica do olhar fenomênico e natural em contemplação intelectiva, a qual, desencobrindo o véu das aparências e da doxa, revelasse a configuração essencial ali oculta.

\section{Os aspectos apofânticos do logos}

Restringir o modo de dar-se da verdade fenomenal aos cercames da facticidade perceptiva, para

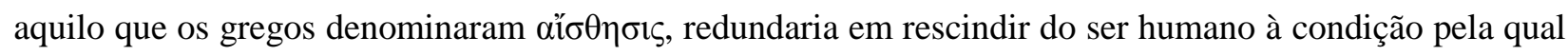
ele mesmo é constituído pela essência de sua humanidade, pela qual é de antemão disposto à compreensão

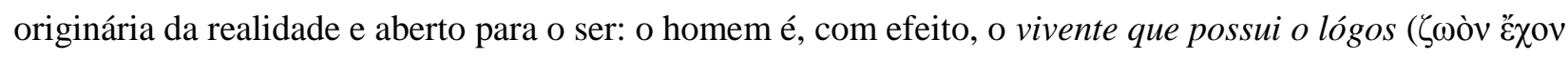
$\lambda o ́ \gamma o v)$ enquanto sua diferença específica aos demais viventes e traço ontológico -existencial constitutivo. Apesar de não podermos destrinçar no momento como se requereria a polissemia da palavra $\lambda$ ó que possamos optar por uma tradução que intentasse traduzi-la no seu aspecto primário, nem que fosse provisoriamente, seja-nos permitido então ao menos aprofundarmo-nos em sua compreensão originária.

Também o $\lambda o ́ \gamma o s$, na medida em que é um fazer ver e mostrar, é uma modalidade da própria $\dot{\alpha} \lambda \hat{\eta} \theta \varepsilon 1 \alpha$, mas como um fenômeno arquetipicamente humano dessa forma de mostração. Com efeito, a respeito da caracterização ontológica desse fenômeno da linguagem diz Heidegger:

$\lambda$ óyos como discurso significa, ao contrário, algo assim como $\delta \eta \lambda$ oṽv, tonar manifesto aquilo de que "se discorre" no discurso. Aristóteles explicitou mais

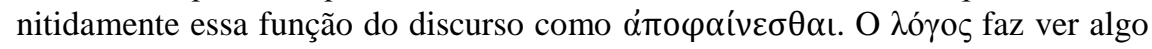

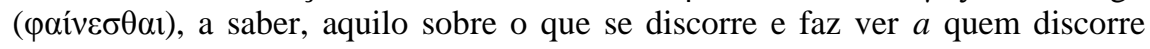
(voz media) e aos que discorrem uns com os outros. O discurso "faz ver" ámò... a partir daquilo mesmo de que se discorre. (...) O "ser-verdadeiro" do $\lambda$ ó $\gamma o \varsigma$ como

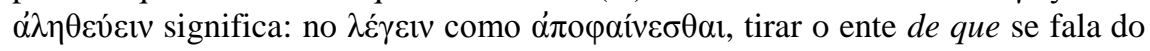
seu encobrimento, fazendo-o ver como não-encoberto, descoberto $(\alpha \dot{\lambda} \eta \theta \dot{\varepsilon} \varsigma)^{5}$.

Pela discursividade do $\lambda$ ó $\varsigma \varsigma$ se perfaz o acontecimento fenomenalizante da linguagem , que potencializa o homem para o desencobrimento noético discursivo da verdade dos entes para além da

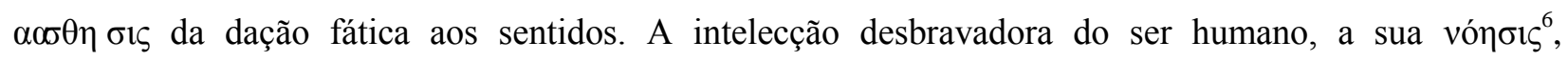

\footnotetext{
${ }^{5}$ HEIDEGGER, Martin. Ser e tempo / Sein und Zeit. Petrópolis: Vozes, 2012, p. 113-115.

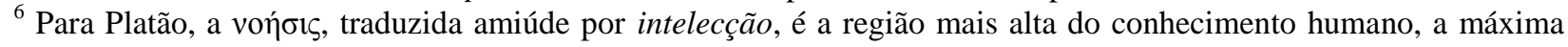
$\dot{\varepsilon} \pi \iota \tau \tau \eta ́ \mu \eta$. Só o filósofo alcançaria esse nível. Contudo, sem a pretensão de nos restringirmos a todas as
}

\begin{tabular}{|c|c|c|c|c|c|}
\hline intuitio & $\begin{array}{c}\text { ISSN } \\
1983-4012\end{array}$ & Porto Alegre & Vol.8 $-\mathrm{N}^{\circ} .1$ & $\begin{array}{c}\text { Junho } \\
2015\end{array}$ & p.157-170 \\
\hline
\end{tabular}


Logos e verdade: uma leitura fenomenológica para o esboço de uma metafísica da linguagem em Platão

sobrelevando-se para além das percepções imediatas, capta os sentidos constituidores dos entes em jogo na percepção e os modos pelos quais estes se configuram e subsistem em sua própria configuração, mesmo a despeito do devir. Em face à fenomenalização do fluxo em constante mudança dos entes, a visão perscrutadora da apreensão intelectiva, apreende a estrutura identitária não só do seu modo de doação, o conspecto fenomenal sob o qual aparecem os entes, mas também sua identidade subjacente a partir da qual

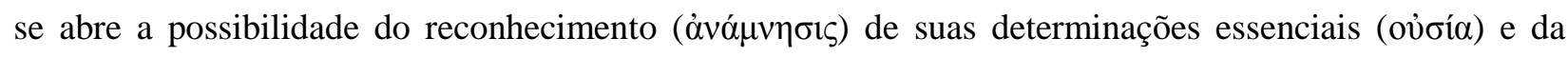

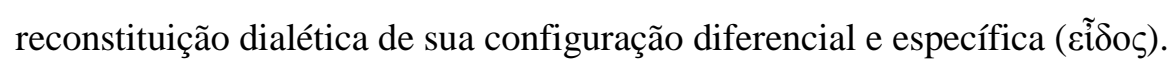

Por isso e em vista disso, o $\lambda o ́ \gamma o \varsigma$ nunca é "imediatamente" (quiçá fora melhor dizer pura $e$ simplesmente) fenômeno, ou melhor, fenomenalização presente em carne e osso do ente do qual se diz, mas possui um caráter apofântico, de um mostrar-se pelo qual o que é mostrado ou é indicado da parte daquilo que fora dado pela percepção ou é descortinado a partir da intelecção compreensiva na qual sua configuração e sentido são apropriados ${ }^{7}$. Por natureza, o desencobrimento dos entes e do seu sentido e significado, realizado pelo $\lambda$ ó ${ }^{\circ} \varsigma$, é sempre um trazer à luz da verdade, que possui como precedência ontológica (não temporal ou fática, mas transcendental) e necessária o próprio acontecer da verdade enquanto desvelamento dos entes a partir dos quais transluz a realidade, dando-se a conhecer.

A realidade dos entes que é entrevista pelo $\lambda o ́ \gamma o \varsigma$ é indicada em Platão por diversas palavras, mas,

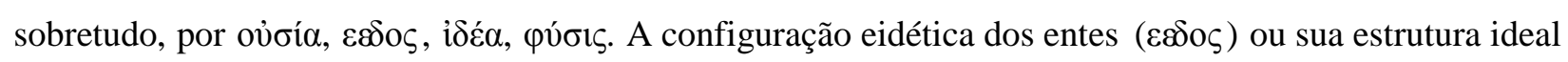
(i $\delta \varepsilon \dot{\alpha} \alpha$ ), subjacentes, mas participativamente presentes $^{8}$ nos fenômenos, é o que torna apreensível a identidade e a diferença dos entes em seu manifestar-se. Através delas podemos dizer o que elas são,

circunscrições do pensamento platônico, não nos detemos ao uso estrito desse termo em Platão.

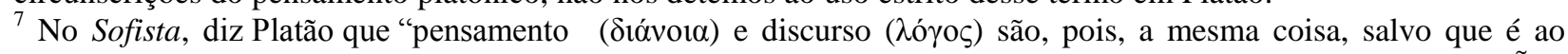

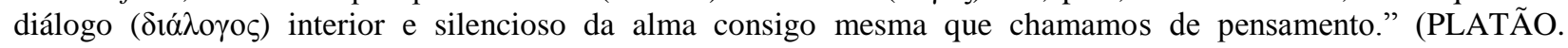
"Sofista". In: _. Pensadores: Diálogos - O Banquete, Fédon, Sofista, Político. São Paulo: Abril Cultural, 1972, 263e, p. 197-198). A dióvola, com efeito, não é apenas a faculdade do conhecimento dos objetos matemáticos (como

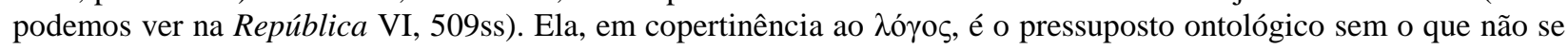
mostra possível ao homem a alcançar a vónбıc. Mais do que um saber estritamente matemático ou geométrico como

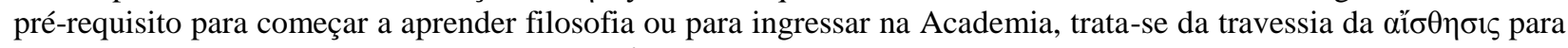
a dimensão inteligível do pensar, que se dá no $\lambda$ ó

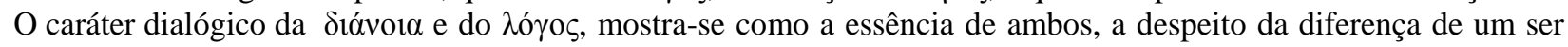
interior e o outro exterior. Esse caráter é, pois, a própria travessia que o dizer e o pensar fazem de antemão, posto que inerente a sua essência mesma, do plano sensível para o plano inteligível (não é nossa pretensão aqui encetar

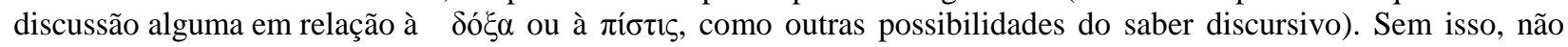
poderia se dar de maneira alguma a dialética. Em outra passagem do Sofista: "Privarmo-nos disso (do $\lambda$ óyoc, no caso,

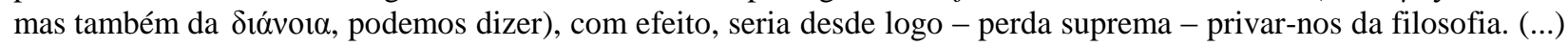
Se dele fôssemos privados (...) isso significaria negar-nos toda possibilidade de discorrer sobre o que quer que fosse (...)" (PLATÃO. "Sofista”. In: __. Pensadores: Diálogos - O Banquete, Fédon, Sofista, Político. São Paulo: Abril Cultural, 1972, 260a-b, p. 193). Desta forma, a dialética, como forma suprema do conhecimento e revelação do ser dos entes, seria terminantemente inviável. E, com isso, a filosofia.

${ }^{8}$ Não é necessário aqui se decidir nessa análise pela doutrina das ideias. O que está se encontra em questão no momento não é nem uma "subjacência" efetiva nem uma participação em um além hiperurânico, mas tão-somente a diferença entre a manifestação do ente enquanto fenômeno e a subsistência real de sua identidade como o irredutível ao seu se mostrar como fenômeno.

\begin{tabular}{|c|c|c|c|c|c|}
\hline intuitio & $\begin{array}{c}\text { ISSN } \\
1983-4012\end{array}$ & Porto Alegre & Vol.8 $-\mathrm{N}^{\circ} .1$ & $\begin{array}{c}\text { Junho } \\
2015\end{array}$ & p.157-170 \\
\hline
\end{tabular}


Logos e verdade: uma leitura fenomenológica para o esboço de uma metafísica da linguagem em Platão

defini-las, circunscrevê-las, apontar quais entes respondem por elas ou a manifestam, quais se relacionam com elas ou não. A sua quididade, portanto, aponta para uma forma arquetípica própria de cada coisa e sem a qual nenhuma coisa poderia ser e subsistir sendo a si mesma. Esta é sua $\varphi v ́ \sigma ı \zeta$, sua raiz ontológica, a

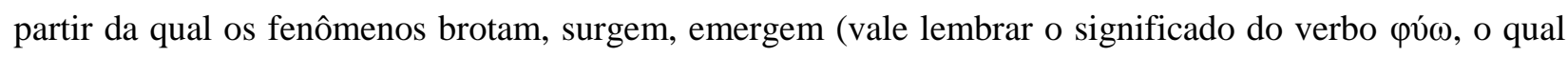
significa justamente brotar, surgir...) como partícipes da matriz essencial que os conserva na vinculação constante de sua própria identidade.

Enquanto ov̉oía, como já disséramos acima acerca de sua ausência presente na vigência do őv, trata-se da raiz que, se ocultando na escuridão do solo não fenomenologizável, no imanifestável, nutre e confere vigor à vigência fenomenal dos entes, cujo modo de ser que lhes é próprio, embora na ausência de não lá vigorar como é em si, se faz presente de algum modo como a ausência da qual devem os entes participar, sem a qual não poderiam manifestá-la e com a qual não poderiam manifestar-se.

Podemos, desta maneira, começar a compreender como que o $\lambda$ ó $\delta \eta \lambda$ oṽv (mostrar, demonstrar, manifestar, indicar, representar, explicar). A referência de Heidegger em Ser e Tempo a esse verbo coincide de fato com a tentativa de Sócrates no diálogo platônico Crátilo de aproximar o $\lambda$ óyos a $\delta \dot{\lambda} \lambda \omega \sigma ı s:$

Sócrates - Logo, se apreendes o que eu digo, é que recebeste de mim uma indicação $(\delta \dot{\eta} \lambda \omega \mu \alpha)$.

Crátilo - Sim.

Sócrates - Indicação $(\delta \eta ́ \lambda \omega \mu \alpha)$ por meio de algo que não se assemelha ao que tenho no espírito quando falo (...). Mas, ainda mesmo que o costume não seja convenção, não é certo dizer que a representação $(\delta \hat{\eta} \lambda \omega \mu \alpha)$ se firma na semelhança. É no costume, pois este, como já vimos, consegue representar ( $\delta \eta \lambda$ ĩ̃) tanto por meio do semelhante como do dissemelhante. E já que chegamos a um acordo, Crátilo (...) forçoso nos será concluir que convenção e costume contribuem igualmente para exprimir ( $\pi \rho$ ò $\delta \dot{n} \lambda \omega \sigma ı)$ o que temos no pensamento ${ }^{9}$.

Ainda que o diálogo tenha terminado em aporia, sem se poder decidir peremptoriamente pelo $\lambda$ ójos como $\delta \dot{\lambda} \lambda \omega \sigma ı \varsigma$ ou se viabilizando ao menos um método firme para assim compreendê-lo, a aproximação entre ambos parece indicar-nos uma coapropriação que nos ensejaria pensar em sua relação essencial $^{10}$. Restituindo essa passagem ao contexto ontológico do qual também faz parte, descurando, porém, da discussão entre Sócrates e Crátilo sobre a naturalidade ou o convencionalismo da confecção e estabelecimento dos nomes, encontramos aqui os fenômenos de indicar, de exprimir ou de representar

${ }^{9}$ PLATÃO. “Crátilo”. In: _ _ . Diálogos IX: Teeteto e Crátilo. Belém: Ed. UFPA, 1973, 435a-b, p. 216.

O que se encontra entre parênteses é acréscimo nosso, com base no texto estabelecido por John Burnet em: Plato. Platonis Opera. Tomus I. Oxford: University Press, 1903, disponibilizado na plataforma on-line do projeto Perseus: http://www.perseus.tufts.edu/hopper/text?doc=Perseus:text:1999.01.0171, acessado em 03 de abril de 2014.

${ }^{10}$ Quanto à potencialidade da linguagem para mostrar o real, diz Sócrates já no começo do diálogo: "Sendo assim, a proposição que se refere às coisas como elas são é verdadeira, vindo a ser falsa quando indica o que elas não são. (...) Logo, é possível dizer por meio da palavra o que é e o que não é." (PLATÃO. "Crátilo". In: Teeteto e Crátilo. Belém: Ed. UFPA, 1973, 385b, p. 147). Diálogos IX:

\begin{tabular}{|c|c|l|l|l|l|}
\hline intuitio & $\begin{array}{c}\text { ISSN } \\
1983-4012\end{array}$ & Porto Alegre & Vol.8 $-\mathrm{N}^{\mathrm{o}} .1$ & $\begin{array}{c}\text { Junho } \\
2015\end{array}$ & p.157-170 \\
\hline
\end{tabular}


Logos e verdade: uma leitura fenomenológica para o esboço de uma metafísica da linguagem em Platão

como pertinentes à dinâmicidade do próprio $\lambda$ ófoç. Estes significados, com efeito, derivam-se todos da compreensão ${ }^{11}$ primária de $\lambda$ ó ${ }_{0}$ c como fenomenalização apofântica. Só porque a linguagem é capaz de fazer referência à dação originária da $\alpha \omega \theta \eta \sigma ı \varsigma$, é que será capaz de assumir um caráter indicativo e apontá-la; e também, porquanto a retome e a reaproprie para si, figurando-a como não-presente em si, mas reapresentada, mostra-se idônea para representá-la, além de ser-lhe possível explicá-la em seus aspectos constitutivos ideacionais, em suas relações, etc.

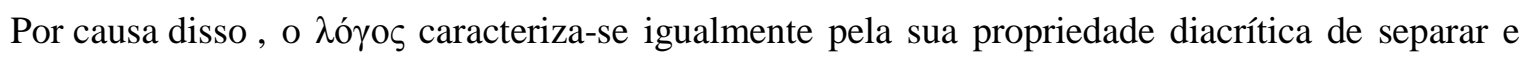
distinguir, além de poder definir e conceituar, compartilhar e instituir significações, sobre cuja

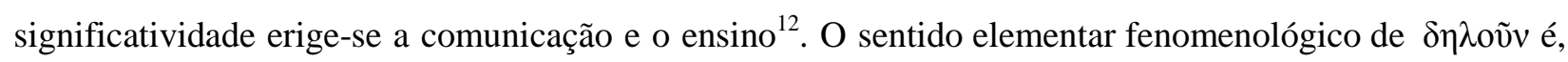
então, o de mostrar a partir de, demonstrar; a demonstração ( $\delta \eta \dot{\lambda} \omega \sigma ı)$, a ação pela qual o mostrar-se parte de algo a fim de mostrá-lo em atividade mesma, converge seu sentido de imediato para a compreensão

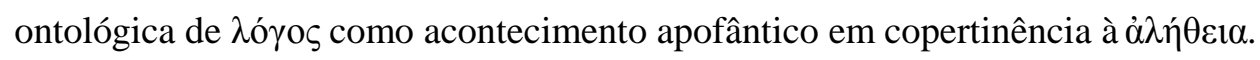

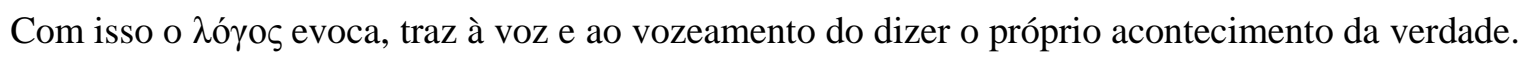
O nomear, o apalavrar, enfim, o conferir ou estabelecer um ővo $\mu \alpha$ retira da distância intangível e atrai para a proximidade fenomênica aquilo que se encontrava oculto. Nada obstante a coisa mesma não possa ser diretamente mostrada, atingida ou deslumbrada, porquanto não nos seja possível transpor os limítrofes de sua ausência nos fenômenos. $\mathrm{O}$ ato de nomear, em conjunção com conferência doadora de sentido pela discursividade, conduz ao horizonte do vislumbre sua manifestação e a possibilidade de se divisá-la ${ }^{13}$. Não há linguagem ou nome para além do horizonte ontológico, e, contudo, não há horizonte sem linguagem ou

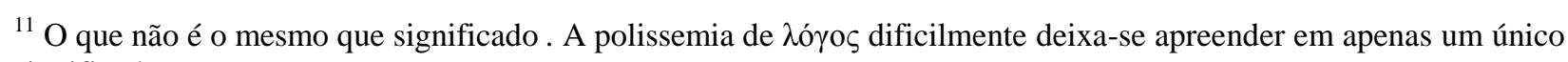
significado.

12 "Socrátes: O nome, por conseguinte, é um instrumento para informar a respeito das coisas e para separá-las, tal como a lançadeira separa os fios da teia." (PLATÃO. "Crátilo". In: Diálogos IX: Teeteto e Crátilo. Belém: Ed. UFPA, 1973, 388b-c, p.152).

E, visto que o nome é uma parte de um todo, que é o $\lambda$ ó $\gamma$ os, isso se aplica também a este. Em relação ao ensino e ao aprendizado, essa definição do nome como um instrumento afasta a tese que o personagem Crátilo procura sustentar, a saber, de que conhecer o nome de uma coisa e o conhecimento da coisa significam o mesmo. Enquanto instrumento para o conhecimento sobre uma coisa - conhecimento que não parte dos nomes , mas da própria coisa -, o nome

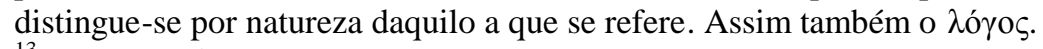

13 "Sócrates (...) na medida em que, partindo da diferença entre logos verdadeiro e logos falso, the (a Hermógenes) faz admitir que também os componentes do logos, as palavras (ỏvó $\mu \alpha \tau \alpha$ ), são verdadeiros ou falsos, e que, portanto, também o nomear, como uma parte do falar, se refere à revelação do ser (ớøía) que se produz no falar." (GADAMER, Hans-Georg. Verdade e método. Petrópolis: Vozes, 1999, p. 595).

Fazemos aqui referência a essa passagem e a grifamos justamente com o intuito de pôr em evidência a capacidade

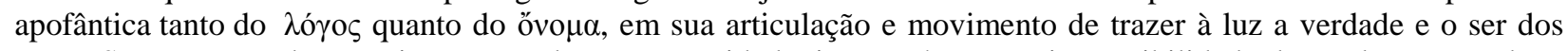
entes. Sem que a ambos esteja assegurada essa capacidade, incorreríamos na impossibilidade de se alcançar o plano noético do conhecimento, o qual, no entanto, apenas é propriamente alcançado subsequentemente pela dialética. Quanto à importância da dialética para a revelação do ser, diz Platão na República que o dialético é quem “(...) apreende a essência de cada coisa.” (PLATÃO. República. Lisboa: Fundação Calouste Gulbenkian, 2010, 534b, p. 348). E também: “(...) a dialética se situa para nós lá no alto como se fosse a cúpula das ciências (...)” (Idem, 2010, 534e, p. 349); entre outras.

Esboçamos alguns pressupostos disso na nota 5, logo acima.

\begin{tabular}{|c|c|l|l|l|l|}
\hline intuitio & $\begin{array}{c}\text { ISSN } \\
1983-4012\end{array}$ & Porto Alegre & Vol.8 $-\mathrm{N}^{\mathrm{o}} .1$ & $\begin{array}{c}\text { Junho } \\
2015\end{array}$ & p.157-170 \\
\hline
\end{tabular}


Logos e verdade: uma leitura fenomenológica para o esboço de uma metafísica da linguagem em Platão

nome a partir dos quais se entreveja o evocado. Do inominável à nomeação fulgura uma relação essencial entre palavra e coisa que talvez não tenha sido senão nomeado (e talvez insuficiente e toscamente) como

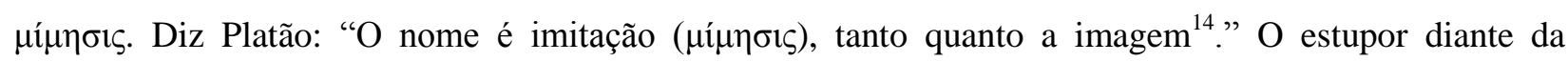
obliteração do inefável em cotejo com o prosaísmo adventício dos fenômenos pode ter precisamente contribuído para se descurar metafisicamente dessa relação em sua grandeza e profundidade. De fato, a motivação metafísica desde já se orientou para a investigação à procura do que responde pelo fundamento,

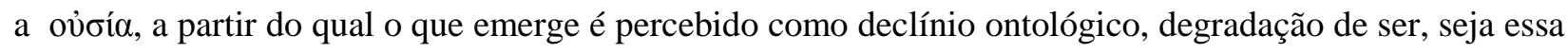
ocorrência mimética, participativa ou causativa.

\section{Alétheia e lógos como formas de mímesis produtivas}

A linguagem mostra-se impérvia para a epifania. Nela o fundamento da essência e sua própria fundação se escondem. Neste sentido, poderíamos retomar as palavras que encerram o Tratactus logicophisophicus de Wittgenstein: "Sobre o que não se pode falar, deve-se calar ${ }^{15}$." E, no entanto, a história da Metafísica testemunha uma contínua transgressão a esses limites. Mas também isto não possui razões casuais e nem se deve pelo descuido acrítico dos filósofos que julgaram natural a via de ascendência dos fenômenos às essências, da participação ao real em si, sem considerar seus limites. De modo algum. Só se pode considerar tais filósofos, como seres sob o fascínio da atitude natural, caso se desconsidere a profundidade e a originalidade de seus questionamentos e investigações, que ingratamente soem em decair ao longo dos tempos na letargia e repetição do dogmatismo. A revolução ptolomaica não foi menos revolucionária que a copernicana: seja girando o sol ao redor da Terra ou o contrário, em ambos a audácia do espírito humano se potencializa para uma compreensão universal e sistêmica das revoluções do universo, do todo e do ser. Assim, não menos perspicaz foi a filosofia antiga para propor questões e a partir delas compreender a realidade.

Em direção a uma interpretação mais profunda dos antigos, escreve Heidegger o seguinte:

Precisamos afastar nesse caso todas as interpretações e retoques modernos desses conceitos antigos. Só podemos fornecer em contornos gerais a comprovação da

\footnotetext{
${ }^{14}$ PLATÃO. "Crátilo”. In: __ _. Diálogos IX: Teeteto e Crátilo. Belém: Ed. UFPA, 1973, 431a, p. 211.

Para explicitar melhor isso: "A palavra é correta quando representa a coisa, isto é, quando é uma representação

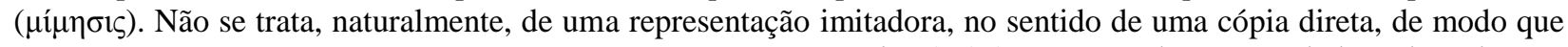
se reproduzisse o fenômeno audível e visível, mas é o ser (ov̉oía) (...) que tem de ser revelado pela palavra." (GADAMER, Hans-Georg. Verdade e método. Petrópolis: Vozes, 1999, p. 596). Por aqui se evidencia o quão devemos evitar uma compreensão demasiadamente tosca e apressada da palavra $\mu$ í

${ }^{15}$ WITTGENSTEIN, Ludwig. Tratactus logicus-philosophicus. São Paulo: Companhia Editora Nacional, 1968, p. 129.
}

\begin{tabular}{|c|c|c|c|c|c|}
\hline intuitio & $\begin{array}{c}\text { ISSN } \\
1983-4012\end{array}$ & Porto Alegre & Vol.8 $-\mathrm{N}^{\circ} .1$ & $\begin{array}{c}\text { Junho } \\
2015\end{array}$ & p.157-170 \\
\hline
\end{tabular}


Logos e verdade: uma leitura fenomenológica para o esboço de uma metafísica da linguagem em Platão

origem das principais determinações antigas para a coisidade do ente a partir do comportamento produtivo, a partir da concepção de ser produtiva ${ }^{16}$.

O que se quer dizer com isso é que a filosofia clássica assumiu perante a compreensão da realidade (a coisidade da coisa e o ser do ente) um comportamento produtivo, de modo a conceber o próprio ser e sua relação com os entes sob o paradigma do modo de produção. ${ }^{17}$ Entre os pré-socráticos,

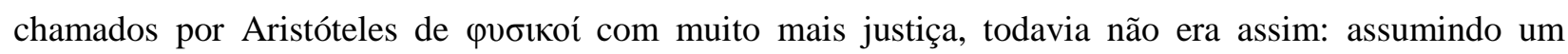
comportamento cultivador face à realidade, tomavam-na como a perpétua geração espontânea e natural ( $\varphi v ́ \sigma ı \varsigma)$ da qual os entes surgem e fenecem, cujo fundamento eterno e princípio (ả $\rho \chi \eta ́)$ jamais s deixa-se entrever em seu estado originário. Quaisquer que tenham sido as influências histórico-culturais para essa não pouco relevante mudança de modelo comportamental que marcou propriamente o início da metafísica do pensamento clássico, isto no momento não vem ao caso. O importante é ressaltar aqui como que o pensamento grego assumiu essa postura como o marco zero de seu horizonte interpretativo a respeito da realidade.

Também com essa postura se encontra comprometida a noção do fenômeno da linguagem e da nomeação no Crátilo. ${ }^{18}$ Por sua vez, diz Heidegger: "Os nomes são palavras que apresentam. Os nomes apresentam o que já é, entregando-os à representação. Mediante essa força de apresentação, os nomes testemunham seu poder paradigmático sobre as coisas." ${ }^{19}$ Só o que já se deu ou se dá à luz da verdade do ser pode ser apresentado pelas palavras. ${ }^{20}$ Em congruência a isso, diz Gadamer, refletindo sobre a linguagem no Crátilo:

${ }^{16}$ HEIDEGGER. Os problemas fundamentais da fenomenologia. Petrópolis: Vozes, 2012, p. 156.

${ }^{17} \mathrm{E}$ isso é eminentemente marcante no pensamento platônico, basta lembrarmos-nos de diálogos capitais dentre o conjunto da obra de Platão, tais como o Timeu (em que a figura do demiurgo constrói o mundo sensível a partir do inteligível) e a República (em que a pólis é um constructo filosófico a partir dos paradigmas conceituais alcançados pela dialética), a título de exemplo. Além disso, são tão numerosas as passagens no corpus platonicus que recorrem ao exemplo ou à analogia com o artesão ou artífice e a seu ofício (a $\tau \dot{\varepsilon} \chi v \eta$ ), para os contextos mais variados contextos, que nos abstemos aqui de citá-las ou fazer referência, posto não ser nosso propósito.

${ }^{18}$ Com diferente intenção, novamente citamos: "O nome, por conseguinte, é instrumento para informar, a respeito das coisas e para separá-las, tal como a lançadeira separa os fios da teia" (PLATÃO. "Crátilo". In: . Diálogos IX: Teeteto e Crátilo. Belém: Ed. UFPA, 1973, 388b-c, p.152). Se à ação de conferir nomes se estabelecerá um vínculo íntimo de analogia com uma produção artesanal, haverá necessidade, pois, de que se postule a quem coube

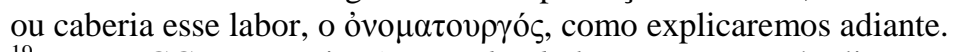

${ }^{19}$ HEIDEGGER, Martin. A caminho da linguagem. Petrópolis: Vozes, 2003, p. 178.

${ }^{20}$ Caso pretendêssemos esmiuçar o texto platônico, seríamos obrigados a considerar uma série de questões que tocam a oposição entre naturalismo X convencionalismo dos nomes, verdadeiro X falso. Uma fala de Sócrates no Crátilo, de fato, aponta para ambas as questões: "Eu também defendo o princípio de que os nomes devem assemelhar-se quanto possível à coisa representada; porém, como disse há pouco Hermógenes, seja bastante precária a tal força de atração da semelhança e que nos vejamos recorrer a esse expediente banal, a convenção, para a correta imposição dos nomes." (PLATÃO. "Crátilo". In:__. Diálogos IX: Teeteto e Crátilo. Belém: Ed. UFPA, 1973, 435d, p. 218) Não nos seria possível, todavia, perquirir por ora tais questões a partir do caminho que traçamos. De qualquer modo, ambas apoiam-se na manifestação prévia do ser como sua condição de possibilidade e na linguagem como modalidade do próprio ser, com o fito de “(...) assegurar ao discurso ( $\lambda$ ó $\mathrm{c} \varsigma$ ) lugar no número dos gêneros do ser" "Sofista”. In: ___ Pensadores: Diálogos - O Banquete, Fédon, Sofista, Político. São Paulo: Abril Cultural,

\begin{tabular}{|c|c|c|c|c|c|}
\hline intuitio & $\begin{array}{c}\text { ISSN } \\
1983-4012\end{array}$ & Porto Alegre & Vol.8 $-\mathrm{N}^{\circ} .1$ & $\begin{array}{c}\text { Junho } \\
2015\end{array}$ & p.157-170 \\
\hline
\end{tabular}


Logos e verdade: uma leitura fenomenológica para o esboço de uma metafísica da linguagem em Platão

Obviamente que a "verdade" da palavra não se apoia na correctura, em sua correta adequação à coisa, mas em sua perfeita espiritualidade, isto é, torna-se patente o sentido da palavra no seu som. Nesse sentido, todas as palavras são verdadeiras, isto é, seu ser se abre em seu significado $(. . .)^{21}$.

A manifestação do ser é a própria condição de possibilidade do acontecimento apofântico da

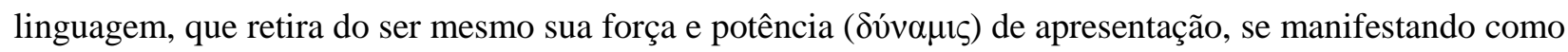
uma das modalidades do próprio ser. O caráter paradigmático deste "poder" deve-se, em todo caso, à própria compreensão da origem fenomenológica da linguagem: tanto a linguagem é originariamente

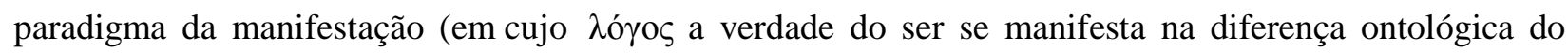
dizer), quanto possui a origem daquilo que diz, enquanto fenômeno do ser na fenomenalização dos entes, a partir dos paradigmas da realidade que se manifestam nesse dizer, embora em si mesmo permaneçam velados.

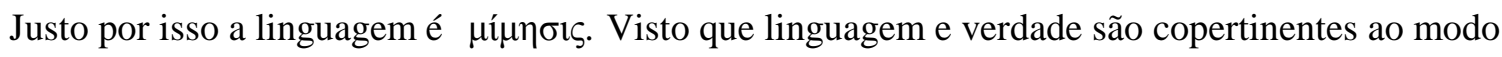
do fazer-se real da realidade, também a verdade, enquanto desencobrimento dos entes, é $\mu$ í $\mu \eta \sigma \varsigma^{22}$. Mas por esse termo não podemos compreender meramente imitação. Outrossim, não o podemos compreender como uma criação completamente original que traz à existência coisas absolutamente singulares , únicas e

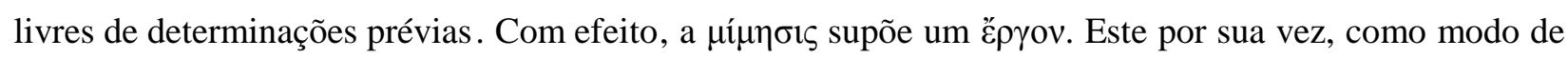
produção próprio dos artesãos imbuídos de uma arte ou técnica ( $\tau \dot{\varepsilon} \chi v \eta)$ para realizá-lo com perfeição, requer, além da matéria-prima bruta e amorfa a ser moldada (vँ $\lambda \eta)$, um paradigma ( $\pi \alpha \rho \alpha ́ \delta \varepsilon \imath \gamma \mu \alpha)$ ou

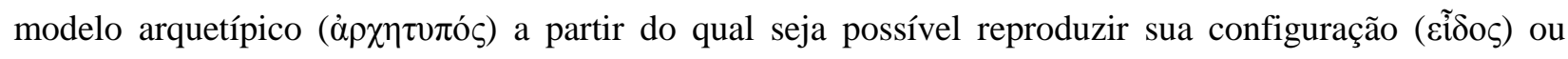

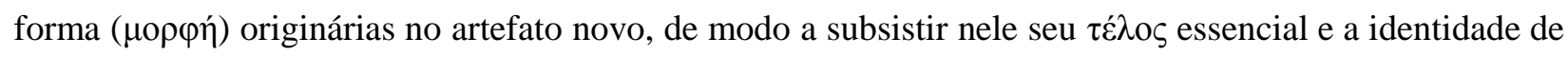
sua ov̉oía, não como mera repetição formal, mas como reprodução essencial de um paradigma em um objeto singular. A $\mu$ í́ $\rceil \sigma \varsigma \varsigma$ é, portanto, o modo de produção dos entes tendo como matriz uma idealidade originária. Também o $\lambda$ ó ${ }^{\circ}$ ç é modo de produção mimético dessas mesmas essências, mas não reprodutivo e sim representativo e justamente por isso em grau menor de apresentatividade, na medida em que supõe,

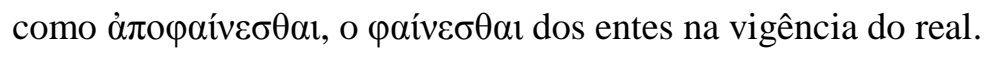

E aqui se insere a necessidade não apenas causal, mas ontológica de alguém que exerça esta produção. No "Timeu" o demiurgo não é um artesão típico que possui tão-só a técnica para a produção; ele é imbuído igualmente do olhar divino filosófico capaz de apreender por sua $\dot{\varepsilon} \pi \iota \tau \eta \dot{\mu \eta}$ a essencialidade das

1972, 260a, p. 193), pressuposto ontológico para essas questões ulteriores.

${ }^{21}$ GADAMER, Hans-Georg. Verdade e método. Petrópolis: Vozes, 1999, p. 598.

${ }^{22}$ Não pensada aqui como, por exemplo, Platão ou Aristóteles pensaram-na, mas refletindo a respeito dela pela copertinência entre linguagem e verdade como modos de dar-se dos entes. De fato, nem Platão, nem Aristóteles

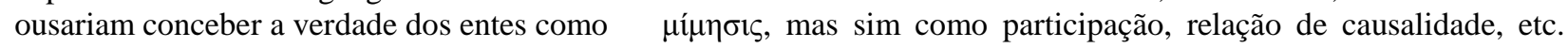
Concebê-la assim incorreria em depreciar necessariamente a natureza, origem do $\theta \alpha \tilde{v} \mu \alpha$ da filosofia. Assumimos aqui esse termo para pensar o modo de produção de desvelamento de ser e linguagem, pois que nele transparece tanto o caráter paradigmático a partir do qual se produz como também da própria ação produtora e reprodutiva.

\begin{tabular}{|c|c|c|c|c|c|}
\hline intuitio & $\begin{array}{c}\text { ISSN } \\
1983-4012\end{array}$ & Porto Alegre & Vol.8 $-\mathrm{N}^{\circ} .1$ & $\begin{array}{c}\text { Junho } \\
2015\end{array}$ & p.157-170 \\
\hline
\end{tabular}


Logos e verdade: uma leitura fenomenológica para o esboço de uma metafísica da linguagem em Platão

coisas ,tais como são em si mesmas e reproduzi-las produzindo pela perfeição de sua perícia o variegado e múltiplo mundo dos entes em devir.

No contexto do "Crátilo", contudo, essa figura divina perfeita não poderia ser de forma alguma admitida como responsável por algo tão imperfeito em seus propósitos como é a linguagem. Entretanto,

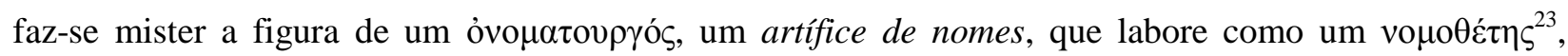
legislador, para o estabelecimento e produção dos nomes, como alguém que os forja e os produz. Sem se poder sustentar a tese da naturalidade dos nomes, o convencionalismo deixa meramente ao encargo desse legislador a confecção dos nomes. É por isso que a figura do $\delta 1 \alpha \lambda \varepsilon \tau \iota \kappa o ́ \varsigma^{24}$, o dialético, é igualmente requerida, pois só ele seria capaz da visão noética necessária para uma justa correção dos nomes, em vista destes se adequarem às coisas mesmas que tencionam representar.

Essa conjunção de forças entre as mãos do legislador e o intelecto do dialético não se mostra capaz o suficiente para uma refundação da linguagem que minimizasse os impactos das convenções e maximizasse a correspondência ontológica. Este projeto é abortado antes mesmo de seus primeiros passos pelo fato de ser descomunal em relação às forças de produção humanas. Ao contrário da produção da natureza, que conta com o divino para configurá-la perfeitamente, nos faltariam lábios e mãos divinas para refundar os nomes e a linguagem.

\section{Considerações finais}

Nos breves apontamentos que fizemos no decorrer do texto, pudemos estabelecer alguns elementos-chave que nos permitiram traçar, em linhas gerais, o esboço de uma metafísica da linguagem em Platão. É evidente que isso não foi suficientemente problematizado e tampouco apresentou-se a intenção de resolver terminantemente suas questões. A análise fenomenológica conduzida até agora, logrou minimamente reconhecer os traços e conexões pelos quais a linguagem está intimamente vinculada à questão do ser e como sua compreensão só pode se dar sobre sua fundamentação na ontologia.

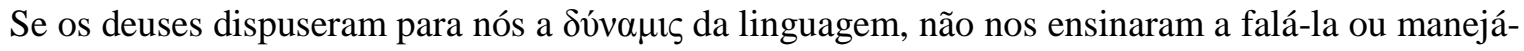
la. Os nomes que dispomos para traduzir a verdade dos entes e do ser se apresentam como instrumentos limitados e não raras vezes ineficazes. Mas são os únicos de que dispomos. Sem eles não há comunicabilidade, não há compartilhamento de sentidos, ensino ou conhecimento. Os deuses teriam

\footnotetext{
23 "Por conseguinte, Hermógenes, nem todos os homens têm capacidade para impor nomes, mas apenas o fazedor de

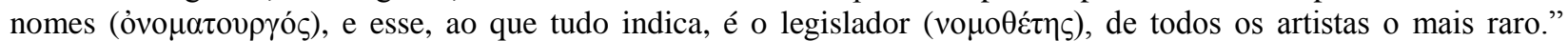
(PLATÃO. "Crátilo". In: ___. Diálogos IX: Teeteto e Crátilo. Belém: Ed. UFPA, 1973, 388e - 389a, p. 153).

${ }^{24}$ PLATÃO. "Crátilo". In:___ . Diálogos IX: Teeteto e Crátilo. Belém: Ed. UFPA, 1973, 390c-d, p. 155.
}

\begin{tabular}{|c|c|c|c|c|c|}
\hline intuitio & $\begin{array}{c}\text { ISSN } \\
1983-4012\end{array}$ & Porto Alegre & Vol. $-\mathrm{N}^{\circ} .1$ & $\begin{array}{c}\text { Junho } \\
2015\end{array}$ & p.157-170 \\
\hline
\end{tabular}


Logos e verdade: uma leitura fenomenológica para o esboço de uma metafísica da linguagem em Platão

escondido de nós em seu silêncio seu idioma etéreo e diáfano capaz de transluzir sem quaisquer vestígios de opacidade e sem mediações a perfeição das coisas tais como são em si mesmas.

Restam-nos os nomes. Resta-nos, destarte, multiplicá-los, expandi-los em sua pragmática, reinventá-los e reoriginá-los. Sem eles não somos os viventes que somos e, por isso, é também deles a missão existencial de povoar a terra e descortiná-la. Os viventes possuem a linguagem, e a linguagem é muito mais do que uma propriedade constitutiva de nosso ser, é a região em que habitamos e que não nos é possível jamais ultrapassar, ainda que enveredemos pelas trilhas mais inóspitas da reflexão e do pensamento onde seja árduo identificar fenômeno, coisa e palavra.

Onde há a grandeza do homem, aí sua miséria. Mas nessa miséria estende-se a largura e a profundidade do horizonte no qual se manifesta para nós o acontecimento da verdade. A grandeza da linguagem, longe de apenas consistir na nossa diferença específica em relação ao gênero dos animais, garante-nos que ao menos que coparticipemos, nos limítrofes em que estamos enredados fenomenicamente, do divino que numenicamente nos é ocultado.

\section{Referências}

GADAMER, Hans-Georg. Verdade e método. Petrópolis: Vozes, 1999.

HEIDEGGER, Martin. A caminho da linguagem. Petrópolis: Vozes, 2003. . "Aletheia”. In:___. Ensaios e conferências. Petrópolis: Vozes, 2012. p.227-249.

_. Os problemas fundamentais da fenomenologia. Petrópolis: Vozes, 2012. . Ser e tempo / Sein und Zeit. Petrópolis: Vozes, 2012.

filosóficos. São Paulo: Abril Cultural, 1996.

INWOOD, Michael. Dicionário Heidegger. Rio de Janeiro: Jorge Zahar, 2002.

PLATÃO. "Crátilo". In:__ _ Diálogos IX: Teeteto e Crátilo. Belém: Ed. UFPA, 1973.

. "Cratylus". In:_. Platonis Opera. Tomus I. Oxford: University Press, 1903.

República. Lisboa: Fundação Calouste Gulbenkian, 2010.

. "Sofista". In: . Pensadores: Diálogos - O Banquete, Fédon, Sofista, Político. São Paulo: Abril

Cultural, 1972. p. 137-203.

WITTGENSTEIN, Ludwig. Tratactus logicus-philosophicus. São Paulo: Companhia Editora Nacional, 1968.

Recebido em: 07/09/2014

Aprovado para publicação em: 17/03/2015

\begin{tabular}{|c|c|c|c|c|c|}
\hline intuitio & $\begin{array}{c}\text { ISSN } \\
1983-4012\end{array}$ & Porto Alegre & Vol.8 $-\mathrm{N}^{\circ} .1$ & $\begin{array}{c}\text { Junho } \\
2015\end{array}$ & p.157-170 \\
\hline
\end{tabular}

